\title{
Transmission Characteristics of Wheat Yellow Striate Virus by its Leafhopper Vector Psammotettix alienus
}

\author{
Zhenzhen Du, Yumei Fu, Yan Liu, ${ }^{\dagger}$ and Xifeng Wang \\ State Key Laboratory for Biology of Plant Diseases and Insect Pests, Institute of Plant Protection, Chinese Academy of Agricultural \\ Sciences, Beijing 100193, China
}

\begin{abstract}
Wheat yellow striate virus (WYSV), which is found in wheat fields of Northwest China and transmitted by leafhopper vector Psammotettix alienus, is a tentative new species in the genus Nucleorhabdovirus. Although the insect vector and host range of WYSV have been characterized, many aspects of the acquisition and transmission processes by its insect vector have not been elucidated. Here, the transmission parameters of WYSV by $P$. alienus were determined using wheat $\mathrm{cv}$. Yangmai 12 as the indicator plant under a controlled temperature $(23 \pm$ $1{ }^{\circ} \mathrm{C}$ ) and photoperiod (16 h of light). The results showed that the minimum periods for acquisition were $5 \mathrm{~min}$ and $10 \mathrm{~min}$ for inoculation ac-

increased with time after acquisition, suggesting that WYSV can replicate in P. alienus. Notably, female P. alienus transovarially transmitted the virus to next generations at relatively high efficiency. Electron microscopy of the WYSV-infected leafhopper revealed bacilliform particles aggregated in the cytoplasm of the salivary gland and midgut tissues. Our present studies suggested that acquisition and transmission of WYSV by $P$. alienus is consistent with a propagative, circulative, and persistent mode of transmission. Details regarding transmission competencies and distribution of WYSV in P. alienus will provide a basis for designing preventive measures.
\end{abstract} cess. The latent period for successful transmission was most commonly 16 to 20 days (minimum, 10 days; maximum, 22 days). The quantitative reverse-transcriptase PCR results indicated that the WYSV titer
Keywords: Wheat yellow striate virus (WYSV), Nucleorhabdovirus, Psammotettix alienus, transmission, propagative
Wheat (Triticum aestivum L.) is an important crop worldwide, but viral diseases pose significant threats to its yield (Wang et al. 2010). It was reported that at least 50 characterized viruses are capable of infecting wheat (Rotenberg et al. 2016). Recently, in Northwest China, we found a novel wheat-infecting nucleorhabdovirus tentatively named wheat yellow striate virus (WYSV) (Liu et al. 2018). Previously described wheat-infecting cytorhabdoviruses include northern cereal mosaic virus (NCMV) (Tanno et al. 2000), barley yellow striate mosaic virus (BYSMV) (Makkouk et al. 1996), and wheat American striate mosaic virus (WASMV) (Seifers et al. 1995). The first two viruses are transmitted by Laodelphax striatellus, but the last one is transmitted by Endria inimica and Elymana virescens. To our knowledge, WYSV is the first nucleorhabdovirus that infects wheat via transmission by Psammotettix alienus (Hemiptera: Cicadellidae). In the field, typical disease symptoms appear on leaf blades as fine yellow striations, and susceptible wheat plants infected at early developmental stages have reduced height and develop ears with few or no seed, resulting in yield reduction. WYSV also infects barley and oat plants, which exhibit different symptoms on golden yellow and deep red leaves, respectively. Based on our field investigation during 2018 and 2019, WYSV has been found in Shaanxi and Hubei province, China, suggesting potential economic risks for widely distributed wheat crops.

Genetic characterization of WYSV revealed that the virus is a negative-sense single-stranded RNA with features typical of rhabdoviruses, including conserved termini, inverted repeats, and highly conserved RNA-dependent RNA polymerase (RdRp) sequences. The full-length genome of WYSV comprises 14,486 nucleotides and encodes the nucleocapsid protein $(\mathrm{N})$, phosphoprotein $(\mathrm{P})$, matrix protein $(\mathrm{M})$, glycoprotein $(\mathrm{G})$, and RNA polymerase (L) core

${ }^{\dagger}$ Corresponding author: Y. Liu; yliu@ippcaas.cn

Funding: This work was financially supported by the National Natural Science Foundation of China grants 31871938 and 31861133020.

The author(s) declare no conflict of interest.

Accepted for publication 11 July 2019.

(C) 2020 The American Phytopathological Society proteins, plus two accessory genes (P3 and P6) in the order $3^{\prime}$ leader-N-P-P3-M-G-P6-L-5' trailer. A phylogenetic analysis grouped WYSV with members of the genus Nucleorhabdovirus and showed two strains of rice yellow stunt virus (RYSV and RTYV) as its closest relative, with $>60 \%$ amino acid identity of the RdRp.

The primary insect vector of WYSV, $P$. alienus, is a major wheat pest that can transmit wheat dwarf virus (WDV; genus Mastrevirus), which annually causes significant yield losses of wheat in Asia, Europe, and North Africa (Derlink et al. 2016; Kumar et al. 2014; Liu et al. 2012; Najar et al. 2000; Schubert et al. 2014). Although the genomic sequences and insect vector of WYSV are known, more research is need to clarify the details of important biological features. The transmission biology of plant rhabdoviruses has been studied extensively, and acquisition and transmission parameters differ depending on the virus and corresponding vector (Jackson et al. 2005). In addition, horizontal transmission is generally regarded to have a primary role in disease outbreaks caused by plant rhabdoviruses, but there is evidence for transovarial transmission in some rhabdovirus-vector combinations (Mann and Dietzgen 2014). To better understand factors that affect the dissemination of WYSV in P. alienus, we investigated the characteristics of vector transmission for WYSV, including the virus acquisition access period (AAP) and inoculation access period (IAP) (acquisition and inoculation times required for transmission, respectively), latent period (LP; the time between virus acquisition and effective transmission), and possible transovarial transmission. We also used a quantitative reverse-transcription PCR (qRT-PCR) and transmission electron microscopy (TEM) to demonstrate the replication and distribution of the virus in P. alienus.

\section{Materials and Methods}

Leafhopper colonies and virus source. The viruliferous population of $P$. alienus used in this study was collected from a wheat field in Hancheng, Shaanxi Province, China. Then, it was established and maintained as stock populations in the laboratory for 3 years. A nonviruliferous population was screened and reared as described previously (Wang et al. 2014). The WYSV (GenBank accession MG604920) isolate was continually maintained on wheat plants using viruliferous leafhoppers, and infections were confirmed by RT-PCR using WYSV-specific primers WYSV-F (5'-CACCAATCGGCAATGAAGCAGT-3') and WYSV-R (5'-ACTCCTGCTACTTGTTGACCTGAA-3'). 
Seedlings of highly susceptible wheat cv. Yangmai 12 were used as source and recipient plants in all transmission assays. Rearing, acquisition, and transmission experiments were performed in growth chambers with a photoperiod of $16: 8 \mathrm{~h}$ (light:dark [L:D]) at $23 \pm 1{ }^{\circ} \mathrm{C}$.

Latent period study. The experimental design used to determine the LP by leafhoppers was similar to that described previously (Conti 1980). First-instar or second-instar nonviruliferous leafhoppers were exposed to WYSV for an AAP of $24 \mathrm{~h}$; then, they were transferred to healthy wheat seedlings at the single-leaf stage (one insect per plant). A 50-ml centrifuge tube was used as an inoculation cage after its bottom was removed and covered with nylon cloth. Each leafhopper used in the transmission assays was identified with a number and transferred to new healthy wheat seedlings at 2-day intervals until the test leafhoppers died. The inoculated plants were maintained in the greenhouse and continuously monitored for symptoms for 4 weeks. Leaves were collected from each plant to test for the presence of WYSV using RT-PCR.

Acquisition access period. After $4 \mathrm{~h}$ of starvation, third-instar or fourth-instar nymphs from the nonviruliferous population were allowed to feed on WYSV-infected plants for 3, 5, 10, 30, 60, or $180 \mathrm{~min}$. For each AAP, 30 nymphs were used. Then, the tested leafhoppers were caged separately on healthy wheat seedlings after each respective AAP. After a 2-week LP on healthy wheat plants, the insects were transferred to an individual wheat seedling for 24-h IAP; then, these plants were grown in a chamber and evaluated for symptom development 3 weeks after inoculation and checked for WYSV infection by RT-PCR. Thirty plants were assayed per treatment, and the experiment was repeated three times.

Inoculation access period. To determine the IAP, we selected third-instar or fourth-instar nymphs from WYSV-infected plants, allowed a 4-day AAP, and then transferred them to healthy plants for different periods. During exploratory tests, we assessed intervals of $3,5,10,30,60$, or $180 \mathrm{~min}$, and each leafhopper was given an identification number that corresponded to a test plant. Thirty plants were assayed per treatment, and the experiment was repeated three times. After each IAP, the leafhoppers were killed by spraying with an insecticide. The percentage of wheat plants that developed virus symptoms was regarded as a measure of the transmission efficiency, which was confirmed by RT-PCR.

Transovarial transmission. For sufficient virus acquisition, nymph leafhoppers were continuously reared on symptomatic WYSVinfected wheat plants. After 4 weeks, gravid females were randomly selected for a transovarial transmission assay and reared singly on a wheat plant, which was replaced with a new one at 2-day intervals. When the oviposition was observed, the adult was tested using an RT-PCR to determine whether it was WYSV-positive. Any eggs laid by viruliferous adults were removed from the plant tissues when the embryos had reached the red eyespot stage. Then, eggs were incubated individually using the water-soaked filter paper culture method (Chen et al. 2016). The individuals were collected at the secondinstar or third-instar stage and tested for virus using the RT-PCR. The percentage of wheat plants that developed virus symptoms was regarded as a measure of the transmission efficiency, and infection was confirmed using the RT-PCR.

qRT-PCR. Fifty adult leafhoppers were placed on a WYSVinfected plant for virus acquisition. After a 2-day AAP, all leafhoppers were transferred to healthy wheat plants (in insect-proof cages). WYSV was quantified from individual leafhoppers sampled at 2, 4, 8 , and 16 days after acquisition using the qRT-PCR. Total RNA was extracted from insect samples with TRIzol reagent and analyzed for real-time qPCR using a SYBR Green qPCR Master Mix Kit with the ABI 7500 Real Time PCR system (Applied Biosystems) and the WYSV N-F: 5'-ATCGGCAATGAAGCAGTCG-3' and WYSV NR: 5'-GGTCCACGCCCTTTAGGTT-3' primers, which corresponded to WYSV N and were expected to amplify a 212-bp fragment for the standard sample. The leafhopper Ribosomal protein 23e (RPS23e) gene (GenBank accession KR012976) was measured in parallel as an internal control with the forward primer 5'-GGTGTTGAAGCTAAG CAGCC-3' and reverse primer 5'-AGTTCAAACAACCGTCCCTG-3'. The PCR cycling conditions were initial denaturation of $94^{\circ} \mathrm{C}$ for $30 \mathrm{~s}$, followed by 40 cycles of $94^{\circ} \mathrm{C}$ for $5 \mathrm{~s}$ and $60^{\circ} \mathrm{C}$ for $34 \mathrm{~s}$. All reactions were performed in three technical and biological replicates. Relative expression levels of the $\mathrm{N}$ gene were calculated using the 2- ${ }^{\Delta \Delta \mathrm{CT}}$ method, and differences between three treatments were analyzed using Duncan's multiple range test with SPSS version 24.0 (IBM, Armonk, NY).

Transmission electron microscopy. To determine viral distribution in leafhoppers, we used TEM to observe salivary glands and midgut tissues from second-instar or third-instar nymphs that had been reared on WYSV-infected wheat for a 1-week AAP and a 3 -week LP. Salivary glands and gut tissues were excised from the viruliferous leafhoppers; then, they were fixed overnight in $2.5 \% \mathrm{vol} /$ vol glutaraldehyde at $4{ }^{\circ} \mathrm{C}$ and postfixed for $1 \mathrm{~h}$ in $1 \% \mathrm{OsO}_{4} \mathrm{wt} / \mathrm{vol}$ in $0.1 \mathrm{M}$ sodium phosphate buffer ( $\mathrm{pH}$ 7.2). They were then dehydrated in an ethanol-acetone series and embedded in araldite CY212 (Agar Scientific, Standsted, UK) using a sequential polymerization process at $37^{\circ} \mathrm{C}$ for $12 \mathrm{~h}, 45^{\circ} \mathrm{C}$ for $12 \mathrm{~h}$, and $60^{\circ} \mathrm{C}$ for $38 \mathrm{~h}$. Ultra-thin $(60 \mathrm{~nm})$ sections of tissue were cut using a Leica EM UC6 Ultramicrotome, stained with $1 \% \mathrm{wt} / \mathrm{vol}$ uranyl acetate in phosphate buffer, and observed with a Hitachi Model H-7500 TEM.

\section{Results}

WYSV-leafhopper interaction parameters that affect transmission. Results of experiments including 24 tested leafhoppers showed that the minimum LP of WYSV was 10 days, and that the maximum was 22 days, with an average of 13 days in the vector P. alienus (Fig. 1). Most (79.2\%) tested leafhoppers transmitted WYSV between 16 and 20 days after a 24-h acquisition feed, suggesting that the LP for WYSV in first-instar and second-instar nymphs is $\approx 2$ to 3 weeks in the laboratory. Of the 24 tested leafhoppers, most viruliferous individuals transmitted WYSV in intermittent periods ranging from 2 to 4 days when reared singly on a wheat plant, which was replaced with a healthy one every 2 days. Only three of 24 tested insects continuously transmitted the virus until they died.

To determine the ability of $P$. alienus to acquire WYSV, nonviruliferous third-instar and fourth-instar nymphs or adults of $P$. alienus were allowed an AAP of 3, 5, 10, 30, 60, or 180 min on WYSVinfected wheat. The average acquisition rates of nymphs and adults after a 3-min AAP were 18.6 and $15.7 \%$, respectively, but no transmission was detected with a 3-min AAP, 24-h IAP, and 2-week LP on test plants. Our data suggested that 5 min of feeding was sufficient for virus acquisition, although the percentage (5.6\%) of WYSV transmitted on test plants was relatively low. Both nymphs and adults transmitted WYSV, and the proportion of infected leafhoppers increased with increasing AAP, from 37.7 and $29.7 \%$ after 10 min to 64.7 and $60.3 \%$ after $3 \mathrm{~h}$, respectively. Collectively, the rates of WYSV acquisition were slightly higher in nymphs than in the adults (Table 1).

As shown in Table 2, none of the plants tested positive for WYSV after 3-min or 5-min IAPs with viruliferous insects; however, after a 10 -min IAP with viruliferous nymphs, $13.3 \%$ of the plants developed infections compared to $7.8 \%$ with adults. However, $>40 \%$ transmission was observed after 1-h IAPs with the vectors, and after 3-h IAPs, the transmission rates for nymphs and adults increased to 60.5 and $57.1 \%$, respectively.

Transovarial transmission. The experimental results showed that WYSV could be transmitted by the progeny of seven of the ten gravid viruliferous females of $P$. alienus. The PCR results for 162 progeny laid by the seven viruliferous females indicated that $73 \mathrm{~F}_{1}$ individuals were WYSV-positive, suggesting that $45.1 \%$ of the offspring carried WYSV. When progeny of one WYSV-positive female were tested singly for infectivity on healthy wheat seedlings, $36.7 \%$ of the plants developed typical disease symptoms. Therefore, our findings indicated that WYSV can be transovarially transmitted by $P$. alienus with high efficiency.

WYSV propagation in adult $\boldsymbol{P}$. alienus. To verify WYSV propagation in $P$. alienus, we analyzed the viral titers in individual leafhoppers sampled at different times after acquisition using qRT-PCR. Differences between three repeat treatments were analyzed using Duncan's multiple range test $(p<0.05)$. Figure 2 shows that the mean 
titer of adults from days 2 to 16 after acquisition from WYSVinfected plants was significantly different. The mean titer at day 16 was significantly higher than that at any other time tested, and it was 4.77-, 4.22-, and 1.88-fold higher than it was at days 2,4 , 8, respectively (Fig. 2). These data revealed that the virus accumulated progressively during the 16 days after acquisition, suggesting that WYSV can propagate in the vector $P$. alienus.

Distribution of WYSV in leafhoppers. As shown in Figure 3, ultrastructural studies revealed numerous virus particles in the salivary gland and midgut tissues of $P$. alienus, and most particles were bacilliform rather than bullet-shaped. Typical bacilliform virions were $\approx 200$ to $270 \mathrm{~nm}$ long and 35 to $40 \mathrm{~nm}$ in diameter, and they appeared to be slightly longer than those found in WYSV-infected wheat leaves (Liu et al. 2018). Large crystalline or paracrystalline aggregates of WYSV particles mainly accumulated in the cytoplasm of the salivary gland and in cytoplasm around the nucleus in midgut cells.

\section{Discussion}

Rhabdoviruses can be acquired from infected plants by their insect vectors during acquisition periods from 1 to $15 \mathrm{~min}$, whereas inoculation thresholds range from a few minutes to several days (Ammar

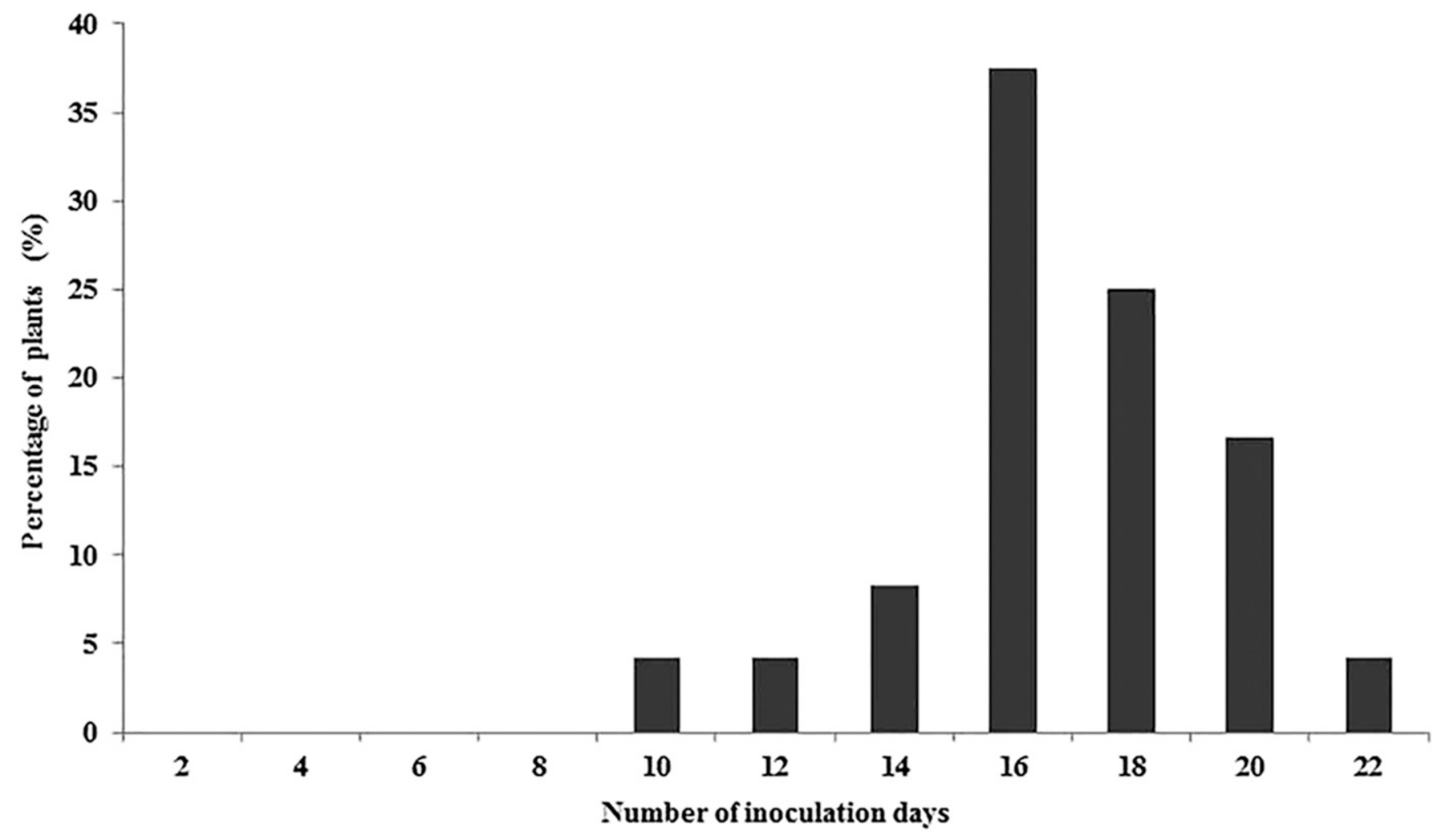

Fig. 1. Latent period of wheat yellow striate virus (WYSV) in the leafhopper $P$. alienus.

Table 1. Transmission of wheat yellow striate virus by third-instar to fourth-instar nymphs and adults of $P$. alienus after different acquisition access periods in a controlled chamber $\left(23 \pm 1^{\circ} \mathrm{C}\right)$

\begin{tabular}{|c|c|c|c|c|c|c|}
\hline \multirow[b]{2}{*}{ Acquisition time } & \multicolumn{3}{|c|}{ Nymphs } & \multicolumn{3}{|c|}{ Adults } \\
\hline & Total no. & No. infected & $\%$ Infected & Total no. & No. infected & $\%$ Infected \\
\hline $3 \min$ & 86 & 16 & 18.6 & 70 & 11 & 15.7 \\
\hline $5 \mathrm{~min}$ & 84 & 29 & 34.5 & 72 & 20 & 27.8 \\
\hline $10 \mathrm{~min}$ & 77 & 29 & 37.7 & 74 & 22 & 29.7 \\
\hline $30 \mathrm{~min}$ & 84 & 43 & 51.2 & 71 & 32 & 45.1 \\
\hline $1 \mathrm{~h}$ & 77 & 47 & 61.0 & 73 & 39 & 53.4 \\
\hline $3 \mathrm{~h}$ & 85 & 55 & 64.7 & 78 & 47 & 60.3 \\
\hline
\end{tabular}

Table 2. Transmission of wheat yellow striate virus by third-instar to fourth-instar nymphs and adults of $P$. alienus after different inoculation access periods in a controlled chamber $\left(23 \pm 1^{\circ} \mathrm{C}\right)$

\begin{tabular}{|c|c|c|c|c|c|c|}
\hline \multirow[b]{2}{*}{ Inoculation time } & \multicolumn{3}{|c|}{ Nymphs } & \multicolumn{3}{|c|}{ Adults } \\
\hline & Total no. & No. infected & $\%$ Infected & Total no. & No. infected & $\%$ Infected \\
\hline $3 \mathrm{~min}$ & 78 & 0 & 0 & 75 & 0 & 0 \\
\hline $5 \mathrm{~min}$ & 79 & 0 & 0 & 77 & 0 & 0 \\
\hline $10 \mathrm{~min}$ & 75 & 10 & 13.3 & 77 & 6 & 7.8 \\
\hline $30 \mathrm{~min}$ & 77 & 24 & 31.2 & 76 & 20 & 26.3 \\
\hline $1 \mathrm{~h}$ & 77 & 37 & 48.1 & 78 & 32 & 41.0 \\
\hline $3 \mathrm{~h}$ & 76 & 46 & 60.5 & 77 & 44 & 57.1 \\
\hline
\end{tabular}


et al. 2009). In the present study, the minimum AAP of 5 min for WYSV was identical to that for rice yellow stunt virus (RYSV) and rice transitory yellowing virus (RTYV) (Chen et al. 1979; Chiu et al. 1968), but much shorter than the 5-h minimum AAP reported for BYSMV and 6-h AAP for sorghum stunt mosaic virus (SSMV) (Conti 1980; Creamer et al. 1997). Surprisingly, WASMV is transmitted by the vector $E$. inimical after it feeds for only $30 \mathrm{~s}$ (Slykhuis 1963). According to our data, after a minimum IAP of $10 \mathrm{~min}$, viruliferous $P$. alienus can transmit WYSV to $\approx 10 \%$ of the tested plants, whereas $>50 \%$ transmission was achieved after 1-h IAP. Previous studies suggested that inoculation thresholds were $<15 \mathrm{~min}$ for BYSMV and 30 min for rice stripe mosaic virus (RSMV), but SSMV was transmitted by the leafhopper Graminella sonora with a minimum IAP of $1 \mathrm{~h}$ (Conti 1980; Creamer et al. 1997; Yang et al. 2017). NCMV has a minimum AAP and IAP of 5 min for the planthopper L. striatellus (Ruan et al. 1983). In general, longer AAPs and IAPs increase transmission efficiencies of plant rhabdoviruses, and they can range from as low as $5 \%$ to as high as $100 \%$ (Hogenhout et al. 2008). In addition, nymphs are usually more susceptible to infection than adults (Nault and Ammar 1989; Todd et al. 2010; Yang et al. 2017). In this study, an increasing proportion of leafhoppers became WYSV-infective as the acquisition period was prolonged to $30 \mathrm{~min}$ or as the inoculation period was prolonged to $1 \mathrm{~h}$. Similarly, the infectivity percentage was always slightly higher in the third-instar and fourth-instar nymphs than in adults after their respective AAPs and IAPs.

Although the LPs of propagative viruses vary in the insect species, the developmental stages of the vectors, temperature, and other environmental factors can affect transmission. LPs of rhabdoviruses in their vectors range from 3 to $>60$ days, with most LPs between 7 and 16 days (Ammar et al. 2009). An LP of 9 to 29 days was reported for BYSMV, and an LP of 5 to 29 days was reported for NCMV, with both transmitted by L. striatellus (Conti 1980; Ruan et al. 1983). However, the minimum LP for WASMV in the leafhopper E. inimical was only 4 days after a 4-day AAP on diseased wheat (Slykhuis 1963). For other leafhopper-transmitted rhaboviruses, the minimum LP of 9 days for SSMV is very similar to that of RTYV, but longer than the 6 days reported for RSMV (Chiu et al. 1968; Creamer et al. 1997; Yang et al. 2017). Our current study showed that the minimum

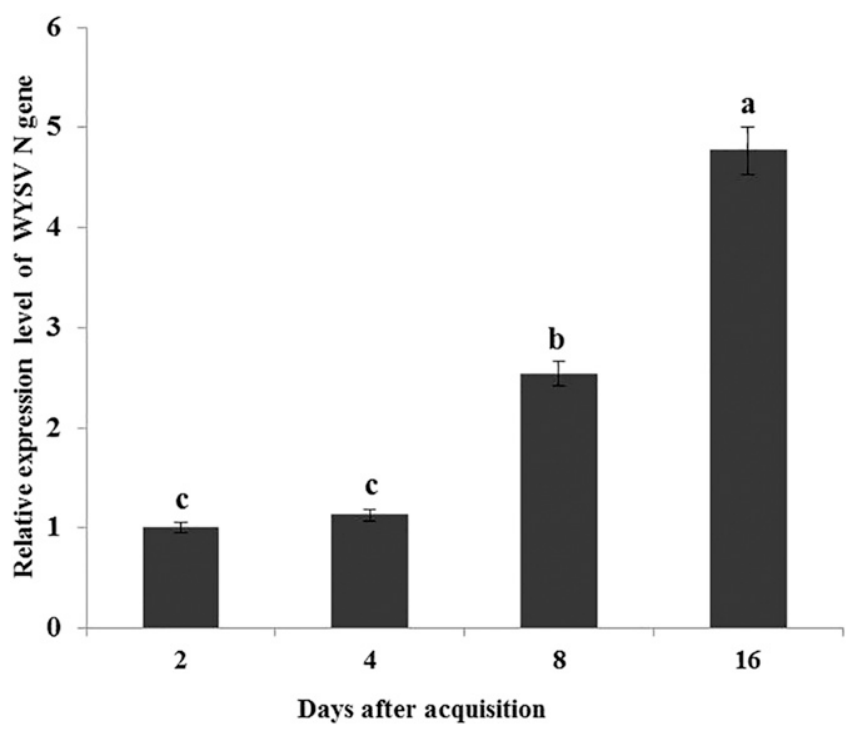

Fig. 2. Comparison of relative RNA levels of wheat yellow striate virus (WYSV) in $P$. alienus after the acquisition access period (AAP) feeding. Samples were collected at 2, 4, 8, and 16 days after the 2-day AAP and analyzed by quantitative reversetranscription PCR (qRT-PCR). Transcript accumulation was calculated according to the $2^{-\Delta \Delta} \mathrm{CT}$ algorithm using RPS23e as the internal reference gene. Values are means \pm standard error from three biological replicates. Means were compared with Duncan's multiple range test. Different letters above the histobars indicate significant differences $(P<0.05)$.
LP of WYSV in P. alienus was 10 days, and that the maximum period was 22 days, even though for most individuals 16 to 20 days was required in our controlled conditions $\left(23 \pm 1^{\circ} \mathrm{C}, 16 \mathrm{~h}\right.$ light $)$. These data and the increasing WYSV titer in $P$. alienus as a function of time after acquisition suggested that the viral titer within the vector is strongly correlated with transmission efficiency.

Numerous plant viruses including RNA and DNA viruses have been shown to be transmitted to progeny (Honda et al. 2007; Huo et al. 2014; Wei et al. 2017). Although transovarial transmission in insect vectors is recognized to have a significant role in the epidemiology of many viruses, much less is known about how this affects diseases caused by plant-infecting rhaboviruses. Early research of rhaboviruses revealed a low amount of transovarial passage of sowthistle yellow vein virus to larvae of the aphid vector Hyperomyzus lactucae (L.) (Sylvester 1969) and for BYSMV to offspring of the planthopper L. striatellus (7.4 to 10.5\%) (Conti 1980). Similarly, leafhopper-transmitted WYSV was also transmitted transovarially to offspring of its vector. Therefore, WYSV can be spread by two common mechanisms: horizontal transmission and vertical transmission.

Similar to the transmission of other persistent plant viruses, successful rhabdovirus transmission ultimately depends on the virus overcoming the midgut membrane and salivary gland barriers (Hogenhout et al. 2008; Martin and Whitfield 2018). In our study, ultrastructural observations showed numerous typical virions in the cells of the midgut membrane and salivary glands, thus providing direct evidence of WYSV infection of the leafhopper bodies. The virus was not found to bud through the plasma or nuclear membrane as MMV virions does (Ammar and Hogenhout 2008). This difference may be related to factors such as the length of time after insect acquisition and the tissues that were sampled. Future immunofluorescence microscopy to trace the dissemination route within the insect should provide information regarding mechanisms that WYSV uses to overcome transmission barriers in $P$. alienus.

In conclusion, WYSV is transmitted by $P$. alienus with much higher efficiency compared with several other rhabdovirus-vector systems. WYSV multiplies in the insects and is transovarially transmitted at a high rate to progeny. These results suggest that $P$. alienus is likely to have great epidemiological importance in the spread of

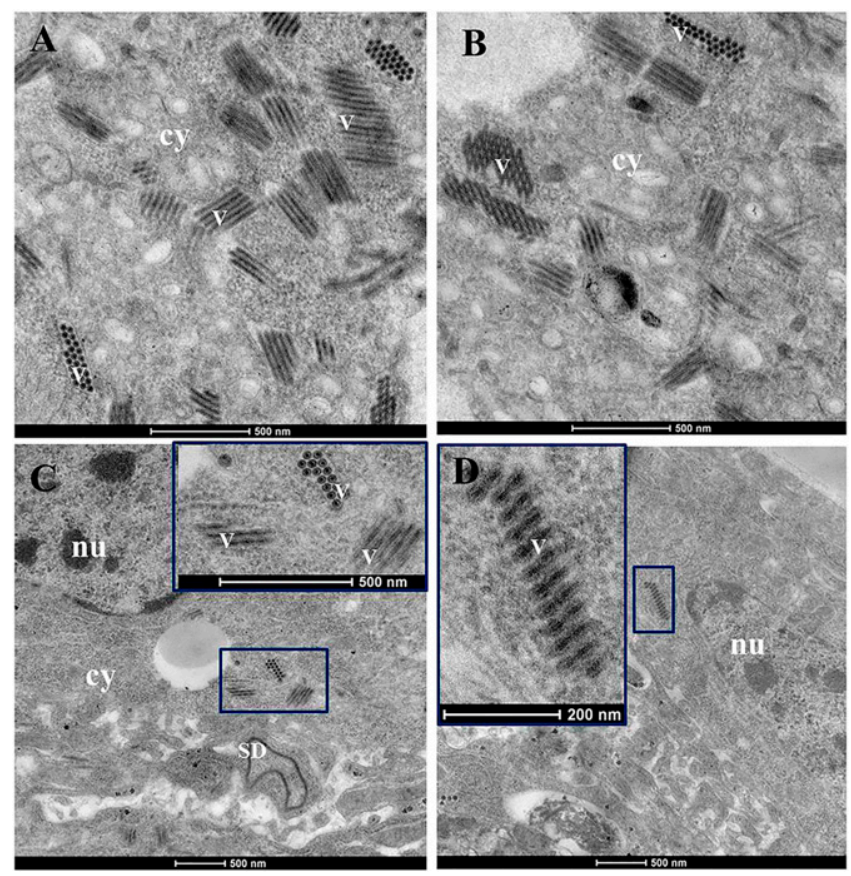

Fig. 3. Transmission electron microscopy (TEM) of wheat yellow striate virus (WYSV) in the salivary gland and midgut cells of $P$. alienus. $\mathbf{A}$ and $\mathbf{B}$, Virions in the cytoplasm of a salivary gland cell. $\mathbf{C}$ and $\mathbf{D}$, Virions in cytoplasm around the nucleus (nu) of midgut cells. Insets in $\mathbf{C}$ and $\mathbf{D}$ show a detailed view of crystalline and paracrystalline aggregates of WYSV particles in boxed areas, respectively. V: virion; cy: cytoplasm; nu: nucleus; SD: septate junctions. 
WYSV. The specific interactions between WYSV and $P$. alienus and molecular mechanisms to overcome biological barriers in the insect vectors require further study. The detailed information regarding transmission characteristics presented here can be used to inform the design of control strategies to reduce populations of these viruses and their leafhopper vectors.

\section{Acknowledgments}

We are grateful to Dr. Zhongkai Zhang (Biotechnology and Germplasm Resources Institute, Yunnan Academy of Agricultural Sciences, China) for providing assistance with transmission electron microscopy.

\section{Literature Cited}

Ammar, E. D., and Hogenhout, S. A. 2008. A neurotropic route for maize mosaic virus (Rhabdoviridae) in its planthopper vector Peregrinus maidis. Virus Res. 131:77-85.

Ammar, E. D., Tsai, C. W., Whitfield, A. E., Redinbaugh, M. G., and Hogenhout, S. A. 2009. Cellular and molecular aspects of rhabdovirus interactions with insect and plant hosts. Annu. Rev. Entomol. 54:447-468.

Chen, S., Yuan, Y., King, D., Chen, K., Lin, R., and Kao, T. 1979. Studies on the development and epiphytotris of the rice yellow stunt disease. Acta Phytopathol. Sin. 9:41-54

Chen, Y., Lu, C. C., Li, M. M., Wu, W., Zhou, G. H., and Wei, T. Y. 2016. Adverse effects of Rice gall dwarf virus upon its insect vector Recilia dorsalis (Hemiptera: Cicadellidae). Plant Dis. 100:784-790.

Chiu, R., Jean, J., Chen, M., and Lo, T. 1968. Transmission of transitory yellowing virus of rice by two leafhoppers. Phytopathology 58:740-745.

Conti, M. 1980. Vector relationships and other characteristics of barley yellow striate mosaic virus (BYSMV). Ann. Appl. Biol. 95:83-92.

Creamer, R., He, X., and Styer, W. E. 1997. Transmission of sorghum stunt mosaic rhabdovirus by the leafhopper vector, Graminella sonora (Homoptera: Cicadellidae). Plant Dis. 81:63-65.

Derlink, M., Abt, I., Mabon, R., Julian, C., Virant-Doberlet, M., and Jacquot, E. 2016. Mating behavior of Psammotettix alienus (Hemiptera: Cicadellidae). Insect Sci. 25:148-160.

Hogenhout, S. A., Ammar, E. D., Whitfield, A. E., and Redinbaugh, M. G. 2008. Insect vector interactions with persistently transmitted viruses. Annu. Rev. Phytopathol. 46:327-359.

Honda, K., Wei, T. Y., Hagiwara, K., Higashi, T., Kimura, I., Akutsu, K., and Omura, T. 2007. Retention of Rice dwarf virus by descendants of pairs of viruliferous vector insects after rearing for 6 Years. Phytopathology 97:712-716.

Huo, Y., Liu, W. W., Zhang, F. J., Chen, X. Y., Li, L., Liu, Q. F., Zhou, Y. J., Wei, T. Y., Fang, R. X., and Wang, X. F. 2014. Transovarial transmission of a plant virus is mediated by vitellogenin of its insect vector. PLoS Pathog 10:e1003949.

Jackson, A. O., Dietzgen, R. G., Goodin, M. M., Bragg, J. N., and Deng, M. 2005. Biology of plant rhabdoviruses. Annu. Rev. Phytopathol. 43:623-660.

Kumar, J., Kumar, J., Singh, S. P., and Tuli, R. 2014. Association of satellites with a mastrevirus in natural infection: complexity of wheat dwarf india virus disease. J. Virol. 88:7093-7104.

Liu, Y., Du, Z. Z., Wang, H., Zhang, S., Cao, M. J., and Wang, X. F. 2018. Identification and characterization of wheat yellow striate virus, a novel leafhoppertransmitted nucleorhabdovirus infecting wheat. Front. Microbiol. 9:468.
Liu, Y., Wang, B., Vida, G., Cséplo-Károlyi, M., Wu, B. L., Wu, Y. H., and Wang, X. F. 2012. Genomic analysis of the natural population of wheat dwarf virus in wheat from China and Hungary. J. Integr. Agric. 11:2020-2027.

Makkouk, K. M., Bertschinger, L., Conti, M., Bolat, N., and Dusunceli, F. 1996. Barley yellow striate mosaic rhabdovirus naturally infects cereal crops in the Anatolian Plateau of Turkey. J. Phytopathol. 144:413-415.

Mann, K. S., and Dietzgen, R. G. 2014. Plant rhabdoviruses: new insights and research needs in the interplay of negative-strand RNA viruses with plant and insect hosts. Arch. Virol. 159:1889-1900.

Martin, K. M., and Whitfield, A. E. 2018. Cellular localization and interactions of nucleorhabdovirus proteins are conserved between insect and plant cells. Virology 523:6-14.

Najar, A., Makkouk, K. M., Boudhir, S. G., Kumari, R., Zarouk, R., Bessai, R., and Othman, F. B. 2000. Viral diseases of cultivated legume and cereal crops in Tunisia. Phytopathol. Mediterr. 39:423-432.

Nault, L. R., and Ammar, E. D. 1989. Leafhopper and planthopper transmission of plant viruses. Annu. Rev. Entomol. 34:503-529.

Rotenberg, D., Bockus, W. W., Whitfield, A. E., Hervey, K., Baker, K. D., Ou, Z. Laney, A. G., De Wolf, E. D., and Appel, J. A. 2016. Occurrence of viruses and associated grain yields of paired symptomatic and nonsymptomatic tillers in Kansas winter wheat fields. Phytopathology 106:202-210.

Ruan, Y. L., Jin, D. D., and Xu, R. Y. 1983. The transmission characteristics of the northern cereal mosaic virus by the small brown planthopper (Laodelphax stritellus Fallén). Acta Phytopathol. Sin. 13:20-21.

Schubert, J., Habekuss, A., Wu, B. L., Thieme, T., and Wang, X. F. 2014. Analysis of complete genomes of isolates of the wheat dwarf virus from new geographical locations and descriptions of their defective forms. Virus Genes 48:133-139.

Seifers, D. L., Harvey, T. L., and Bowden, R. L. 1995. Occurrence and symptom expression of American wheat striate mosaic virus in wheat in Kansas. Plant Dis. 79:853-858.

Slykhuis, J. T. 1963. Vector and host relations of north american wheat striate mosaic virus. Can. J. Bot. 41:1171-1185.

Sylvester, E. S. 1969. Evidence of transovarial passage of the sowthistle yellow vein virus in the aphid Hyperomyzus lactucae. Virology 38:440-446.

Tanno, F., Nakatsu, A., Toriyama, S., and Kojima, M. 2000. Complete nucleotide sequence of northern cereal mosaic virus and its genome organization. Arch. Virol. 145:1373-1384.

Todd, J. C., Ammar, E. D., Redinbaugh, M. G., Hoy, C., and Hogenhout, S. A 2010. Plant host range and leafhopper transmission of maize fine streak virus. Phytopathology 100:1138-1145.

Wang, X. F., Liu, Y., Han, C. G., Wu, Y. F., and Zhao, Z. H. 2010. Present situation and development strategies for the research and control of wheat viral diseases. Plant Prot. 36:13-19.

Wang, Y. J., Mao, Q. Z., Liu, W. W., Mar, T. T., Wei, T. Y., Liu, Y., and Wang, X. F. 2014. Localization and distribution of wheat dwarf virus in its vector leafhopper, Psammotettix alienus. Phytopathology 104:897-904.

Wei, J., He, Y. Z., Guo, Q., Guo, T., Liu, Y. Q., Zhou, X. P., Liu, S. S., and Wang, X. W. 2017. Vector development and vitellogenin determine the transovarial transmission of begomoviruses. Proc. Natl. Acad. Sci. USA 114:6746-6751.

Yang, X., Zhang, T., Chen, B., and Zhou, G. H. 2017. Transmission biology of rice stripe mosaic virus by an efficient insect vector Recilia dorsalis (Hemiptera: Cicadellidae). Front. Microbiol. 8:2457. 